\title{
KHULU' (TALAK TEBUS) DAN IMPLIKASI HUKUMNYA DALAM PERSPEKTIF HUKUM ISLAM
}

\author{
Henderi Kusmidi*
}

\section{Abstrak}

Dalam masyarakat kita sering menjumpai berbagai macam kasus atau kejadian rumah tangga, seperti keretakan rumah tangga yang berujung pada perceraian, namun lazimnya hak cerai itu dimiliki oleh laki-laki (suami). Akan tetapi bukan berarti hal ini menunjukan bentuk diskriminasi terhadap wanita, karena hukum Islam telah memberikan solusi bagi wanita yang mengalami gencatan atau beban rumah tangga untuk melakukan gugatan cerai pada suami, dengan cara memberikan upah atau iwadh sebagai tebusan dan bentuk membebaskan dirinya dari ikatan suami istri.

Kata Kunci : Cerai, Gugat (khulu'), Implikasi dan Hukum Islam

\section{Pendahuluan}

Pada zaman Jahiliyyah suami berhak menceraikan isterinya dengan tidak ada batasnya meskipun sudah menceraikannya seratus kali, selama si isteri berada pada masa iddah. Mereka tidak mengenal perikemanusiaan atau keadilan dalam memperlakukan isteriisterinya. Sampai datangnya Nabi Muhammad SAW yang sama sekali tidak menyutujui kebiasaan perceraian tersebut. Beliau menghilangkan kebiasaan ini secara bertahap karena kebiasaan ini telah mendarah daging di zaman jahiliyah. Hukum Islam memberi jalan kepada isteri yang menghendaki perceraian dengan mengajukan khulu', sebagaimana hukum Islam memberi jalan kepada suami untuk menceraikan isterinya dengan jalan talak.

Nikah merupakan suatu ibadah yang dianjurkan oleh agama dan sebagai ittiba' Rasululullah SAW. Tujuan dari nikah itu sendiri adalah membentuk keluarga sakinah, mawaddah, warahmah dan juga membentuk keturunan yang kuat dalam Bergama. Namun seiring berjalannya waktu banyak masalah yang timbul ketika dua orang telah menikah tersebut menemui suatu masalah yang 
sukar untuk dihadapi. Kadang hal tersebut membuat isteri mengajukan permintaan cerai terhadap sang suami. Apalagi saat ini hal tersebut sudah menjadi fenomena yang tak asing lagi. Banyak sosial media yang menayangkan tentang kasus-kasus perceraian yang didasari permintaan seorang isteri kepada suaminya untuk bercerai. Berangkat dari banyak hal tersebut penulis mencoba menjelaskan mengenai permintaan cerai seorang isteri kepada suaminya atau dalam istilah fiqh disebut: "khulu'"

\section{A. Pengertian khulu'}

Khulu' adalah talak yang diucapkan oleh suami dengan pembayaran dari pihak isteri kepada suami. Perceraian semacam ini diperbolehkan oleh hukum Islam. ${ }^{1} \quad$ Khulu adalah kesepakatan perceraian antara suami isteri atas permintaan isteri dengan imbalan sejumlah uang atau harta yang diserahkan kepada suami, sebagaimana disebutkan dalam Al-Qur'an Surat Al Baqarah 2 : 229

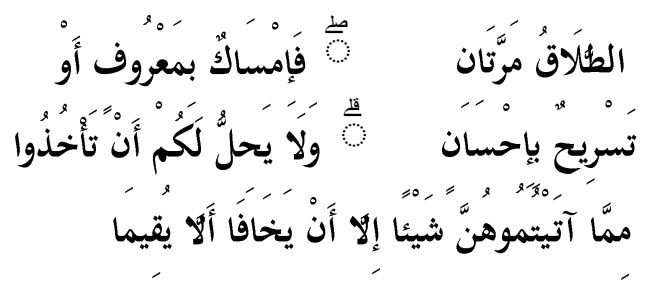

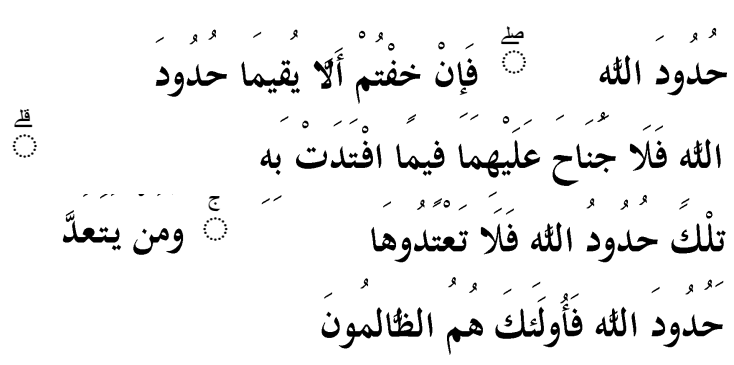

Talak (yang dapát dirujuki) dua kali. Setelah itu boleh rujuk lagi dengan cara yang ma'ruf atau menceraikan dengan cara yang baik. Tidak halal bagi kamu mengambil kembali sesuatu dari yang telah kamu berikan kepada mereka, kecuali kalau keduanya khawatir tidak akan dapat menjalankan hukum-hukum Allah. Jika kamu khawatir bahwa keduanya (suami isteri) tidak dapat menjalankan hukum-hukum Allah, maka tidak ada dosa atas keduanya tentang bayaran yang diberikan oleh isteri untuk menebus dirinya. Itulah hukum-hukum Allah, maka janganlah kamu melanggarnya. Barangsiapa yang melanggar hukum-hukum Allah mereka itulah orang-orang yang zalim. ${ }^{2}$

Gugatan cerai, dalam bahasa Arab disebut Al-Khulu' (الخُعْمُ ). Kata Al-Khulu' ( الَُلْعُ) dengan didhommahkan hurup kha'nya dan disukunkan huruf Lam-nya, berasal dari kata ( خُلْعُ الْنْوْ ب). Maknanya melepas pakaian. Lalu digunakan untuk istilah wanita yang meminta kepada suaminya untuk melepas dirinya dari ikatan pernikahan yang dijelaskan Allah sebagai pakaian. Allah SWT berfirman: 


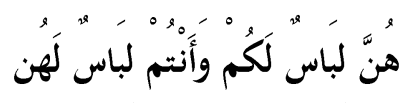

"Mereka itu adalah pakaian, dan kamu pun adalah pakaian bagi mereka"(Al-Baqarah : 187). ${ }^{3}$

Sedangkan menurut pengertian syari'at, para ulama mengatakan dalam banyak defenisi, yang semuanya kembali kepada pengertian, bahwasanya Al-Khulu ialah terjadinya perpisahan (perceraian) antara sepasang suami-isteri dengan keridhaan dari keduanya dan dengan pembayaran diserahkan isteri kepada suaminya.4 Adapun Syaikh Al-Bassam berpendapat, Al-Khulu' ialah perceraian suami-isteri dengan pembayaran yang diambil suami dari isterinya, atau selainnya dengan lafazh yang khusus" 5

Di dalam Islam, jika suami merasa dirugikan dengan perilaku maupun kondisi isterinya, ia berhak menjatuhkan talak, begitu pula sebaliknya, jika isteri merasa dirugikan dengan perilaku dan kondisi suaminya, ia dapat mengajukan gugatan cerai, yang dikenal dengan istilah khulu'. Khulu' dalam istilah fikih dinamakan juga tebusan, karena isteri menebus dirinya dari suaminya dengan mengembalikan mas kawin sebagaimana yang dia terima ketika pernikahan. Menurut ahli fikih, khulu' adalah isteri memisahkan diri dari suaminya dengan ganti rugi. Khulu' dapat dilakukan apabila ada alasan pembenar, misalnya suami tidak dapat memenuhi kewajibannya, cacat fisik yang dapat mengganggu keharmonisan, suami berperilaku jelek dan sebagainya yang dapat mencegah tercapainya tujuan perkawinan. Khulu' dapat terjadi dengan persetujuan atau tanpa persetujuan suami, jika tidak tercapai persetujuan suami dan isteri, pengadilan dapat menjatuhkan khulu' kepada suami.

Para ulama' di antaranya Abdurrahman al-Jaziri memberikan definisi khulu' yaitu menurut masing-masing madzhab di antaranya adalah: 6

1. Golongan Hanafi mendefinisikan : "Khulu' ialah menanggalkan ikatan pernikahan yang diterima oleh istri dengan lafadz khulu' atau yang semakna dengan itu."

2. Golongan Syafi'i memberikan definisi khulu' : “Khulu' menurut syara' adalah lafadz yang menunjukkan perceraian antara suami istri dengan tebusan yang harus memenuhi persyaratan tertentu."

3. Golongan Maliki memberikan definisi khulu': "khulu' menurut syara' adalah thalaq dengan tebusan."

4. Golongan Hanabillah mendefinisikan khulu' : "khulu” adalah suami 
menceraikan istrinya dengan tebusan yang diambil oleh suami dari istrinya atau dari lainnya dengan lafadz tertentu."

Abu Zahrah mendefinisikan bahwa khulu mempunyai dua arti yaitu 'am dan khas. Khulu dalam arti umum adalah talak atas harta istri untuk menebus dirinya yang diserahkan kepada suaminya baik dengan lafazh khulu atau lafazh mubaro'ah atau dengan lafazh talak. Pengertian ini banyak digunakan oleh ulama kontemporer. Adapun khulu' dalam arti khas adalah talak tebus dengan lafazh khulu, pendapat ini banyak digunakan oleh ulama salaf. ${ }^{7}$

Menurut Al-Malibariy, khulu' adalah perceraian dengan tebusan dari pihak isteri diberikan pada pihak suami, dengan memakai kata talak atau khulu' atau tebusan. ${ }^{8}$ Khulu adalah jalan keluar bagi isteri yang tidak menyukai suaminya dengan alasan selain yang biasa melahirkan fasakh, isteri memberikan semacam ganti rugi (iwadh) atas pemberian suami seperti mahar dan nafkah agar suami bersedia dengan rela hati menjatuhkan talak kepadanya. ${ }^{9}$
Al-Jurzawi menuturkan: Khulu' sendiri sebenarnya dibenci oleh syari'at yang mulia seperti halnya talak. Semua akal dan perasaan sehat menolak khulu', hanya Allah SWT saja Yang Maha Bijaksana memperbolehkannya untuk menolak bahaya ketika tidak mampu menegakan hukum-hukum Allah SWT.10 Maksudnya Hikmah khulu untuk menghindari bahaya, yakni saat terjadinya pertengkaran hebat yang menimbulkan gejolak dalam hubungan suami isteri hingga keduanya tidak bisa disatukan lagi dalam ikatan rumah tangga maka khulu diperbolehkan. Hal ini agar keduanya tetap berjalan dalam kehidupan masingmasing dan menjalankan kewajibannya sebagai hamba Allah. ${ }^{11}$ Khulu' adalah penyerahan harta yang dilakukan oleh isteri untuk menebus dirinya dari ikatan suaminya. ${ }^{12}$ Khulu' adalah suatu perceraian dimana seorang isteri membayar sejumlah uang sebagai iwadh atau pengganti kepada suaminya. Khulu' berasal dari kebiasaan masyarakat Arab sebelum islam yang semula merupakan 
pengembalian mas kawin atau pemberianpemberian sewaktu bercerai. ${ }^{13}$

Dari beberapa pengertian diatas dapat disimpulkan bahwa khulu' adalah perceraian dengan disertai sejumlah harta sebagai iwadh yang diberikan oleh isteri kepada suami untuk menebus diri agar terlepas dari ikatan perkawinan.

\section{B. Landasan Hukum Khulu'}
Al-Khulu
disyariatkan
dalam

syari'at Islam berdasarkan firman Allah SWT

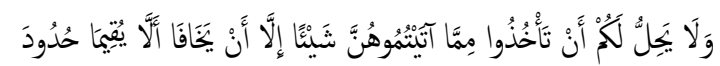

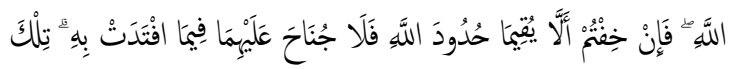

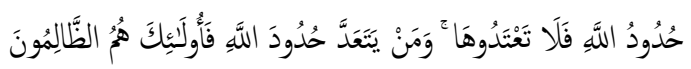

"Tidak halal bagi kamu mengambil kembali sesuatu dari yang telah kamu berikan kepada mereka, kecuali kalau keduanya khawatir tidak akan dapat menjalankan hukum-hukum Allah. Jika kamu khawatir bahwa keduanya (suami-isteri) tidak dapat menjalankan hukum-hukum Allah, maka tidak ada dosa atas keduanya tentang bayaran yang diberikan oleh isteri untuk menebus dirinya. Itulah hukum-hukum Allah, maka janganlah kamu melanggarnya. Barangsiapa yang melanggar hukum-hukum Allah, mereka itulah orang-orang yang zhalim' (Al-Baqarah : 229)
Sabda Rasulullah SAW dalam hadits Ibnu Abbas Radhiyallahu ‘anhuma.

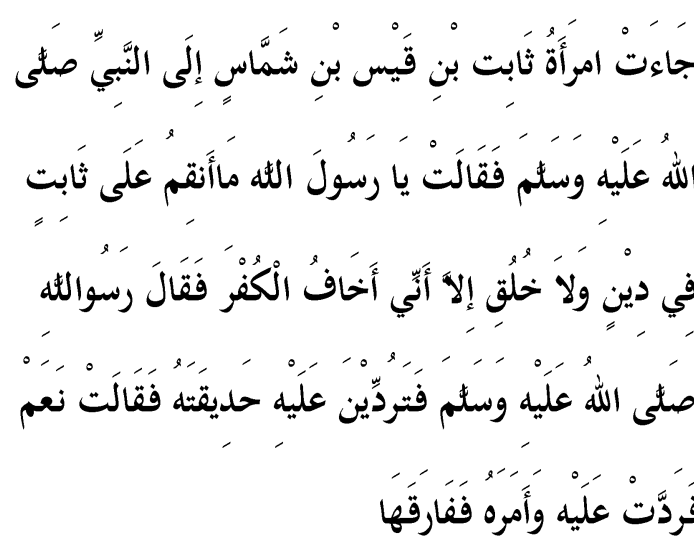

"Isteri Tsabit bin Qais bin Syammas mendatangi Nabi Shallallahu 'alaihi wa sallam seraya berkata ; "Wahai Rasulullah, aku tidak membenci Tsabit dalam agama dan akhlaknya. Aku hanya takut kufur". Maka Rasulullah Shallallahu 'alaihi wa sallam bersabda: "Maukah kamu mengembalikan kepadanya kebunnya?". Ia menjawab, "Ya", maka ia mengembalikan kepadanya dan Rasulullah Shallallahu 'alaihi wa sallam memerintahkannya, dan Tsabit pun menceraikannya" (HR Al-Bukhari). ${ }^{14}$

Hadits Tentang Gugatan Cerai (khulu')

$$
\text { حدثنا خالد عن عكرمة عن ابن عباس أن امرأة ثابت أندر بن حميل قال }
$$

ابن قيس أتت النبي صلى الله عليه وسلم فقالت يارسول الله ثابت بن قيس أما إني ماأعيب عليه في خلق ولادين 
ولكني أكره الكفر في الإسلام فقال رسول الله صلى الله عليه وسلم أتردين عليه حديقته قالت نعم قال رسول الله

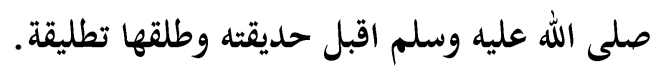

Artinya :"Aku telah diberi khabar oleh sahabat Azhar bin Jamil, beliau berkata: telah bercerita kepadaku sahabat Abdul Wahab, beliau berkata: telah bercerita kepadaku sahabat Kholid, yang ia peroleh dari sahabat Ikrimah, yang bersumber dari Ibnu Abbas. Sesungguhnya istri sahabat Tsabit bin Qois datang mengadu kepada Nabi SAW, dan berkata: "Wahai utusan Alloh, Tsabit bin Qois itu tidak ada kurangnya dari segi kelakuannya dan tidak pula dari segi keberagamannya.Cuma saya tidak senang akan terjadi kekufuran dalam Islam". Kemudian Rasulullah SAW bersabda: "Maukah kamu mengembalikan kebunnya?". Kemudian si istri menjawab: "ya mau". Nabi SAW berkata kepada Tsabit: "Terimalah kebun itu dan ceraikanlah dia satu kali cerai". 15

Hadits diatas menunjukkan tentang adanya hak khulu' bagi wanita, dalam artian istri bisa menggugat cerai suami dengan cara memberi ganti rugi atau iwadh kepada suami dengan jalan khulu' (gugatan cerai istri), sang istri bisa memiliki dirinya sendiri, dalam artian dia bebas dari ikatan perkawinan, walaupun pada dasarnya hak menceraikan itu dimiliki oleh suami. Dari uraian hadits diatas memberikan petunjuk, bahwa dalam proses khulu' terdapat pemberian ganti rugi iwadh kepada suami, dalam hal ini menurut interpretasi para ulama ahli fiqh dihukumi wajib dan menjadi syarat dalam akad khulu'.

Dalam hadits lain Rasulullah SAW bersabda

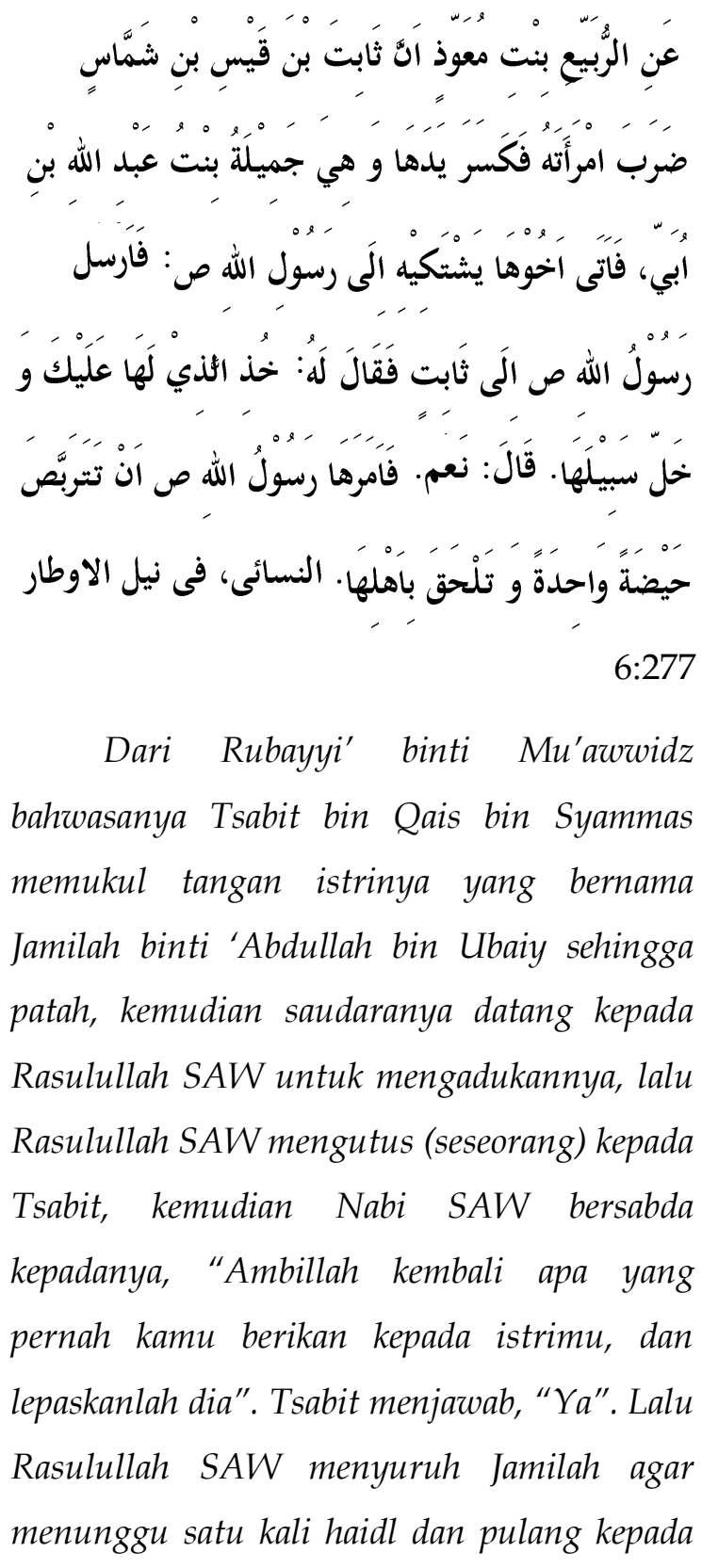


keluarganya". (HR. Nasai, dalam Nailul Authar juz 6, hal. 277)

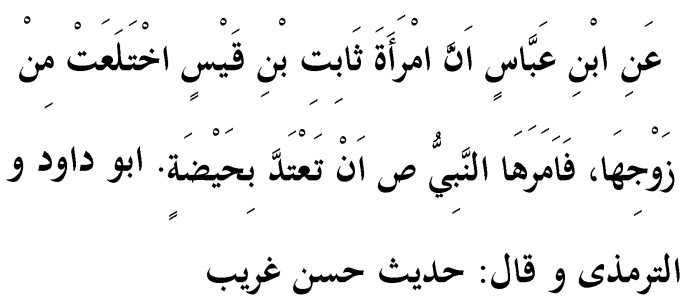

Dari Ibnu 'Abbas bahwasanya istri Tsabit bin Qais menebus dirinya dari suaminya, kemudian Nabi SAW menyuruhnya supaya ber'iddah sekali haidl. (HR. Abu Dawud dan Tirmidzi, dan ia berkata, "Hadits hasan gharib, dalam Nailul Authar juz 6, hal. 277)

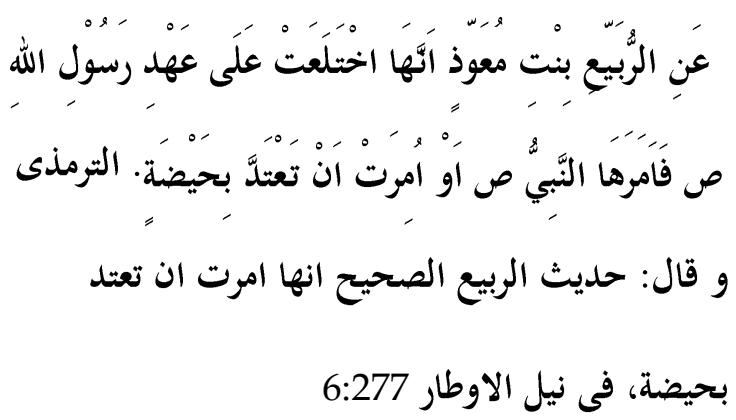

Dari Rubayyi' binti Mu'awwidz, bahwasanya ia pernah menebus dirinya (khulu') di masa Rasulullah SAW, kemudian Nabi SAW menyuruhnya atau dia disuruh agar ber'iddah sekali haidl. (HR. Tirmidzi, dan ia berkata, "Hadits Rubayyi' ini sah, bahwa ia disuruh oleh Nabi SAW agar ber'iddah dengan sekali haidl, dalam Nailul Authar juz 6, hal. 277)

\section{Syarat dan Rukun Khulu'}

Khulu' dianggap sah apabila telah memenuhi beberapa unsur di antaranya syarat dan rukun. Adapun dalam setiap rukun khulu' mempunyai syarat yang masing-masing harus ada pada rukun tersebut. Untuk lebih jelasnya mengenai syarat-syarat Khulu' jika tampak adanya bahaya yang mengancam dan merasa takut keduanya tidak akan dapat menegakkan hukum-hukum Allah. Hendaknya khulu' itu berlangsung sampai selesai tanpa adanya tindakan penganiayaan (menyakiti) yang dilakukan oleh suami terhadap istrinya. Jika ia menyakiti istrinya, maka ia tidak boleh mengambil sesuatu pun darinya. Khulu' itu berasal dari istri dan bukan dari pihak suami. Jika suami yang merasa tidak senang hidup bersama dengan istrinya, maka suami tidak berhak mengambil sedikitpun harta dari istrinya. Khulu' sebagai thalak bain, sehingga suami tidak diperbolehkan meruju'nya kembali, kecuali setelah mantan istrinya menikah dengan laki-laki lain dan kemudian melalui proses akan nikah yang baru.

Adapun yang menjadi rukun dari khulu' adalah :

1. Suami yang menceraikan istrinya dengan tebusan

2. Istri yang meminta cerai dari suaminya dengan tebusan 
3. Uang tebusan atau ganti rugi atau iwadh.

4. Sighat atau ucapan cerai

Alasan untuk terjadinya Khulu' Bagi Suami :

Syarat suami yang menceraikan istrinya dalam bentuk Khulu' sebagaimana yang berlaku dalam thalak adalah seorang yang ucapannya telah diperhitungkan secara syara, yaitu akil, baligh, dan bertindak atas kehendaknya sendiri dan dengan kesengajaan. Berdasarkan syarat ini. Bila suami masih belum dewasa atau suami sedang dalam keadaan gila pula maka yang akan menceraikan dengan nama khulu' adalah walinya. Demikian pula bila keadaan seseorang yang berada di bawah pengampuan karena kebodohannya, yang menerima permintaan khulu' istri adalah walinya. Dalam hal tersebut seluruh madzhab sepakat bahwa baligh dan berakal merupakan syarat yang wajib dipenuhi oleh laki-laki yang melakukan Khulu'. Sedang Hambali mengatakan, Khulu' sebagaimana halnya dengan thalak, dianggap sah bila dilakukan oleh orang yang mumayyiz (telah mengerti sekalipun belum baligh), mereka juga sepakat tentang sahnya khulu' yang dilakukan oleh orang safih, tetapi uang (harta) tebusannya harus diserahkan kepada walinya.
Istri yang dikhulu' kepada suaminya disyaratkan hal-hal sebagai berikut:

1. Ia adalah seseorang yang berada dalam wilayah suami, dalam arti istrinya atau yang telah diceraikan, masih berada dalam iddah raj'i.

2. Ia adalah seorang yang telah dapat bertindak atas harta, karena untuk keperluan.

\section{Alasan yang membolehkan isteri minta cerai}

Meskipun khulu diperbolehkan tetapi harus diikuti dengan alasan-alasan yang kuat, seperti suami seorang pemabuk, pezina, penjudi, tidak menafkahi keluarganya dan lain-lain. Dalam hal seorang wanita atau isteri meminta cerai tanpa alasan atau dicaricari, maka diharamkan untuknya bau syurga. Sesuai dengan hadits Nabi SAW:

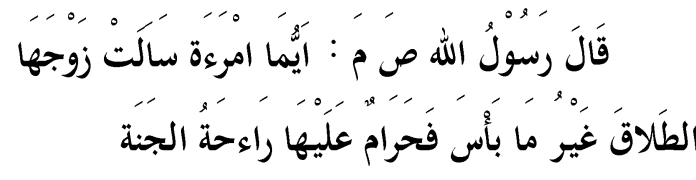

Artinya: "Dari Tsauban, Rasul SAW bersabda: "Siapapun perempuan yang meminta cerai kepada suaminya tanpa sebab, maka haram baginya bau syurga". ${ }^{16}$ 
Berdasarkan dalil-dalil Al Qur'an serta Hadist tersebut cukuplah menjadi fakta kekuatan pengadilan dalam menangani kasus khulu. Sehingga untuk melindungi hak wanita dalam perkawinan, pemberian hak khulu kepada wanita sangat diperlukan guna menghindari hal-hal yang tidak diinginkan terjadi. Khulu' baru boleh dilakukan apabila betul-betul ada alasan syar'i antara lain :17

1. Suami cacat tubuhnya atau buruk akhlaknya

2. Suami suka menyakiti jasmani isterinya

3. Suami tidak menunaikan kewajiban dan tanggungjawabnya

4. Isteri khawatir akan semakin jauh dari Allah SWT.

Adapun tujuan khulu' dalam Islam adalah memberi kelonggaran kepada seorang wanita untuk melepaskan diri dari suaminya dengan suatu tebusan manakala ia merasa ada bahaya yang mengancamnya, jika ia terus berada dibawah kekuasaan suaminya. Karena suami yang zalim atau karena sebab yang lain yang tidak keluar dari aturan syar'i. 18

Wanita tidak boleh menyatakan khulu' selain sebab yang disyari'atkan, sebagaimana sabda Rasulullah SAW :

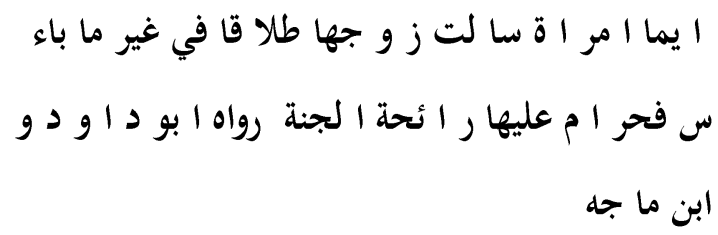

Wanita yang meminta suaminya agar menjatuhkan talak kepadnya tanpa suatu alasan yang dibenarkan, maka haram baginya aroma syurga". (HR. Abu Daud dan Ibnu Majah.)

Tidak diperbolehkan bagi wanita untuk mengajukan khulu' dari suaminya, sedang ia sendiri tidak ingin berpisah darinya. Mungkin karena desakan orang tuanya. Ketaatan kepada suaminya lebih utama dari pada ketaatan kepada mereka berdua, selama suami tidak menyuruhnya melakukan suatu kemaksiatan. ${ }^{19}$

\section{E. Khulu' diluar Pengadilan}

Khulu' sebagaimana halnya talak, dapat dilakukan secara langsung antara suami istri tanpa melibatkan hakim dan pengadilan agama. Seperti dikatakan Imam Nawawi dalam Al-Majmuk Syarh al-Muhadzab:

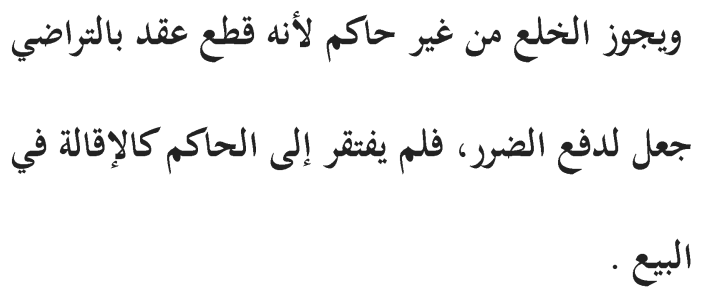

Khulu' dapat dilakukan tanpa hakim karena khuluk merupakan pemutusan akad 
dengan saling sukarela yang bertujuan untuk menolak kemudaratan. Oleh karena itu ia tidak membutuhkan adanya hakim sebagaimana iqalah dalam transaksi jual beli.20

Walaupun khulu' dapat dilakukan di luar pengadilan, namun secara formal itu tidak diakui negara. Untuk mengesahkannya secara legal formal menurut undang-undang Indonesia, maka pihak yang berperkara tetap harus mengajukannya ke Pengadilan Agama. ${ }^{21}$ Harus juga diingat, bahwa proses perceraian di Pengadilan Agama dapat dilakukan apabila memenuhi sejumlah persyaratan yang ditentukan. Seperti, terjadinya kekerasan dalam rumah tangga (KDRT), suami tidak memberi nafkah, ditinggal suami selama 2 tahun berturutturut dan lain-lain. ${ }^{22}$

\section{F. Khulu' dalam Pengadilan Agama}

Suatu gugatan perceraian akan diakui negara dan akan memiliki kekuatan legal formal apabila dilakukan di Pengadilan Agama dan diputuskan oleh seorang Hakim. ${ }^{23}$ Untuk mengajukan gugatan cerai atau khulu', seorang istri atau wakilnya dapat mendatangi Pengadilan Agama (PA) di wilayah tempat tinggalnya. Bagi yang tinggal di Luar Negeri, gugatan diajukan di PA wilayah tempat tinggal suami. Bila istri dan suami sama-sama tinggal di luar negeri, maka gugatan diajukan kepada Pengadilan Agama di wilayah tempat keduanya menikah dulu. ${ }^{24}$

Berbeda dengan khulu' yang dilakukan di luar Pengadilan, maka gugat cerai yang diajukan melalui lembaga pengadilan harus memenuhi syarat-syarat antara lain:

1. Suami berbuat zina, pemabuk, pemadat, penjudi dan sebagainya;

2. Suami meninggalkan isteri selama 2 (dua) tahun berturut-turut tanpa ada ijin atau alasan yang jelas dan benar artinya suami dengan sadar dan sengaja meninggalkan isteri;

3. Suami dihukum penjara selama (lima) 5 tahun atau lebih setelah perkawinan dilangsungkan;

4. Suami bertindak kejam dan suka menganiaya isteri;

5. Suami tidak dapat menjalankan kewajibannya sebagai suami karena cacat badan atau penyakit yang dideritanya;

6. Terjadi perselisihan dan pertengkaran terus menerus tanpa kemungkinan untuk rukun kembali;

7. Suami melanggar taklik-talak yang diucapkan suami saat ijab-kabul; 
8. Suami beralih agama atau murtad yang mengakibatkan ketidakharmonisan dalam keluarga. ${ }^{25}$ Syarat-syarat di atas tentu saja harus disertai dengan adanya saksi dan bukti-bukti yang menguatkan gugatan.

9.

\section{G. Implikasi Hukum Khulu'}

Khulu' (Talak Tebus) boleh dilakukan baik waktu suci maupun sewaktu haid karena biasanya terjadinya talak tebus atas kemauan isteri. Perceraian yang dilakukan dengan talak tebus berakibat bekas suami tidak dapat rujuk lagi dan tidak boleh menambah talak sewaktu iddah, hanya dibolehkan kawin kembali dengan aqad baru. ${ }^{26}$ Khulu' sendiri merupakan alternatif fiqh didalam meringankan beban berat dari masalah rumah tangga, contoh akad khulu' adalah wanita atau istri mengucapkan kepada suaminya:"Ceraikanlah aku dan engkau akan mendapatkan ganti rugi atau iwadh dari saya berupa uang seribu dirham". Akad khulu' yang sah itu mempunyai implikasi hukum bahwa tertalak ba'in-nya wanita yang melakukan khulu'.

Khulu' boleh dengan pembayaran yang ditentukan, dengan khulu' itu seorang wanita berkuasa atas dirinya. Laki-laki tidak boleh kembali kepadanya kecuali dengan nikah yang baru. ${ }^{27}$ Dampak/akibat hukum khulu', terdapat persoalan apakah perempuan yang menerima khulu' dapat diikuti dengan talak atau tidak? Imam Malik berpendapat bahwa khulu' itu tidak dapat diikuti dengan talak, kecuali jika pembicaraannya bersambung. Sedangkan Imam Abu Hanifah mengatakan dapat diikuti tanpa memisahkan antara penentuan waktunya, yaitu dilakukan dengan segera atau tidak. Perbedaan pendapat ini terjadi karena golongan pertama berpendapat bahwa iddah termasuk hukum talak. Sedangkan Imam Abu Hanifah berpendapat termasuk hukum nikah. Oleh karena itu ia tidak membolehkan seorang menikahi perempuan yang saudara perempuannya masih dalam iddah talak bain. Bagi fuqaha' yang mengatakan bahwa iddah termasuk dalam hukum pernikahan, mereka berpendapat bahwa khulu' tersebut dapat diikuti dengan talak. Sedang fuqaha' yang berpendapat demikian, mengatakan bahwa khulu' tersebut tidak dapat diikuti dengan talak. 28

Persoalan yang lain adalah jumhur fuqaha' sepakat bahwa suami dapat menikahi mantan isterinya yang di khulu' pada masa iddah dengan persetujuannya. 
Sedangkan fuqaha' mutaakhirin tidak membolehkan. Kemudian fuqaha' berselisih pendapat tentang iddah wanita yang di khulu' apabila terjadi persengketaan antara suami isteri berkenaan dengan dengan kadar harta yang dipakai untuk terjadinya khulu'. Adapun Imam Malik berpendapat bahwa yang dijadikan pegangan adalah kata-kata suami jika tidak ada saksi. Sedang Imam Syafi'i berpendapat bahwa kedua suami isteri saling bersumpah, dan atas isteri dikenakan mahar mitsil. Beliau mempersamakan persengketaan antara suami dengan persengketaan antara dua orang yang jual beli. Adapun Imam Malik memandang isteri sebagai pihak tergugat dan suami sebagai penggugat. ${ }^{29}$

Ketika seorang suami telah menjatuhkan khulu' atas istrinya dengan tebusan yang disepakati dan tebusannya telah dibayarkan, terjadilah perpisahan antara keduanya dan putuslah hubungan keduanya yang diistilahkan "bainunah shugra' (perpisahan kecil)", suami tidak mempunyai hak rujuk. Berkata AsySyaikh Al 'Alaamah Muhammad Al Utsaimin rahimahullah: "Wanita yang telah pisah karena khulu' tidak ada rujuk 48 dan tidak mungkin bagi suaminya untuk rujuk' kepadanya kecuali dengan pernikahan yang baru"30

\section{H. Tujuan dan Hikmah Khulu'}

Maksudnya Hikmah khulu' untuk menghindari bahaya, yakni saat terjadinya pertengkaran hebat yang menimbulkan gejolak dalam hubungan suami isteri hingga keduanya tidak bisa disatukan lagi dalam ikatan rumah tangga maka khulu' diperbolehkan. Hal ini agar keduanya tetap berjalan dalam kehidupan masingmasing dan menjalankan kewajibannya sebagai hamba Allah. ${ }^{31}$ Kebolehan khulu' adalah untuk menghindakan isteri dari kesulitan dan kemadharatan yang dirasakan apabila perkawinan dilanjutkan tanpa merugikan pihak suami karena dia sudah menerima iwadh dari istrinya atas permintaan cerai dari istrinya itu. Hikmah dari hukum khulu' adalah tampaknya keadilan Allah sehubungan dengan hubungan suami istri. Apabila suami berhak melepaskan diri dari hubungan 
dengan istrinya menggunakan cara thalaq, istri juga mempunyai hak dan kesempatan bercerai dari suaminya dengan menggunakan cara khulu'.

Khulu' adalah untuk mencegah terjadinya pelanggaran-pelanggaran hukum-hukum Allah dalam kehidupan suami istri akibat kebencian istri terhadap jeleknya akhlak, agama, ataupun fisik suami. Adapun Hikmah khulu' dapat kemukakan sebagai berikut :

1. Mengelakkan isteri nusyuz kepada suami.

2. Penghormatan kepada kaum perempuan karena mereka mempunyai hak untuk bertindak mengikut peraturan yang telah ditetapkan oleh syara'.

3. Memberi keinsafan kepada suami supaya menyedari kesilapan dan kesalahannya terhadap isteri demi kebaikan masa depan.

\section{Kesimpulan}

Menunjukkan bahwa Islam memberlakukan keadilan untuk wanita dalam ruang lingkup rumah tangga, hal ini dibuktikan adanya hak khulu' bagi wanita. Kebolehan khulu' itu adalah untuk menghindarkan si istri dari kesulitan dan kemudaratan yang dirasakannya bila perkawinan dilanjutkan tanpa merugikan pihak si suami karena ia sudah mendapat iwadh dari istrinya atas permintaan cerai dari istrinya itu.

Hukum khulu' itu adalah tampaknya keadilan Allah sehubungan dengan hubungan suami istri. Apabila suami berhak melepaskan diri dari hubungan dengan istrinya menggunakan cara thalaq, istri juga mempunyai hak dan kesempatan bercerai dari suaminya dengan menggunakan cara khulu'. Hal ini didasarkan kepada pandangan fiqh bahwa perceraian itu merupakan hak mutlak seorang suami yang tidak dimiliki oleh istrinya, kecuali dengan cara lain atau alasan-alasan yang dibenarkan oleh syara'.

\section{Referensi}

1. Diterbitkan oleh Proyek Peningkatan Sarana Keagamaan Islam, Zakat dan Wakaf Direktorat Jenderal Bimas Islam dan Urusan Haji, Pedoman Fiqh Munakahat, Jakarta, Tahun 1999/2000, hal. 28

2. QS. Al-Baqarah $2: 229$

3. QS. Al-Baqarah $2: 187$

${ }^{4}$. Shahih Fiqhis Sunnah, 3/340

5. Syaikh Abdullah bin Abdurrahman AlBasam, Maktabah Al-Asadi, Taudhihul Ahkam Min 
Bulughul Maram Cetakan Kelima, Makkah Tahun 1423H, hal. 468

6 . H. Djamaan Nur, Fiqh Munakahat, Semarang: Dina Utama, 1993, hlm. 150-151.

7. Muhammad Abu Zahrah, Ahwal Syahkshiyyah, (Kairo: Daar el-Fikri, 2005), hal. 329

8. Syeikh Zainuddin bin Abdul Aziz AlMalibariy, Fathul Mu'in Syarah Qurrot el-Aini, (Semarang: Pustaka Alawiyyah, 1997), hal. 111

9. Abdul Wahhab Muhaimin, "Kajian AyatAyat Hukum Wanita Dalam Perkawinan Dan Perceraian", Jurnal Ahkam, no 4 (Maret1998), hal. 44

10. Ali Ahmad Al-Jurzawi, Hikmah Al-

Tasyri Wa Falsafatuh, (Falsafah Dan Hikmah

Hukum Islam), Penerjemah: Hadi Mulyo Dan Sabahus Surur, (Semarang: CV As-Syifa, 1992), hal. 320

11 . Ali Ahmad Al-Jurjawi, Indahnya Syariat Islam, (Jakarta; Gema Insani, 2006), hal. 379

12. Muhammad Jawad Mughniyah, Fiqh Lima Mazhab Edisi lengkap, Penerbit PT. Lentera Basritama, Jakarta, 1996, hal. 456

13. Daniel S. Lev, Alih Bahasa H. Zaini Ahmad Noeh, Peradilan Agama Islam di Indonesia (Suatu Studi Tentang Landasan Politik Lembaga-lembaga Hukum Cetakan Kedua, Penerbit PT Intermasa, Jakarta, 1986, hal. 210

14. Abu Abdullah Muhammad bin Yazid AlQazwaini ‘Ibnu Majah', Sunan Ibnu Majah, hal. 663

15. Kitab Sunan Nasa'i Juz V, hal. 168

16. Zalaluddin bin Abdurrahman bin Abu Bakar As-suyuthi, Jamie el-Shagir Fi Ahadis Basyir el-Nazir, (Kairo: Darr el-Katib el-Arabi, 1967), hal. 106

17. Muhamad Fuad, Fiqh Wanita Lengkap (Mengupas Sisi Hukum Wanita dalam Kehidupan Sehari-hari), Penerbit Lintas Media, Cetakan Pertama, Jombang, 2007, hal. 482

18. Muhamad Fuad, Fiqh Wanita Lengkap (Mengupas Sisi Hukum Wanita dalam Kehidupan Sehari-hari), hal. 483

19. Syaikh Abu Malik Kamal bin As-Sayyid Salim, Panduan Beribadah Khusus Wanita (menjalankan Ibadah Sesuai Tuntunan Al-Qur'an dan As-Sunnah Cetakan Kedua, Penerbit Almahira,2008, hal. 529
${ }^{20}$. Imam Nawawi, Al-Majmuk Syarh al-

Muhadzab, XVII, hal. 13

${ }^{21}$. KHI (Kompilasi Hukum Islam), Bab

XVI Pasal 114

${ }^{22}$. KHI (Kompilasi Hukum Islam), Bab

XVI Pasal 116

23. Pasal 1 Bab I Ketentuan Umum PP No 9/1975 tentang Pelaksanaan UU No 1 tahun 1974 tentang Perkawinan

${ }^{24}$. Pasal 73 UU No 7/1989 Tentang

Peradilan Agama

${ }^{25}$. Pasal 116 Kompilasi Hukum Islam (KHI) Jo Pasal 19 PP No 9 tahun 1975.

26. Diterbitkan oleh Proyek Peningkatan Sarana Keagamaan Islam, Zakat dan Wakaf Direktorat Jenderal Bimas Islam dan Urusan Haji, Pedoman Fiqh Munakahat, Jakarta, Tahun 1999/2000, hal. 28

27. Mustof Diibul Bigha, Fiqh Syafi'i (Terjemah ST Tahdzib), Penerbit Bintang Pelaja, tahun 1984, hal. 386

28. Slamet Abidin, Fikih Munakahat 2,

(Bandung: CV Pustaka Setia, 1999), hal. 95

29. Ibnu Rusydi, Bidayatul Mujtahid Wa

Nihayatul Muktashid Jilid 2, hal. 52.

${ }^{30}$. Fathu Dzil Dzalalil Wal Ikraam Bi Syarhi Bulughil Maraam 4, hal. 653

${ }^{31}$. Ali Ahmad Al-Jurjawi, Indahnya Syariat Islam, (Jakarta; Gema Insani, 2006), hal. 379 